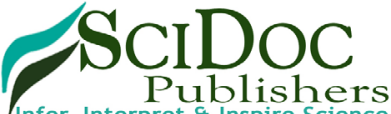

Publishers

\title{
Insights into the Possible Mechanisms By Which Platelet-Activating Factor and PAF-receptors Func- tion in Vascular Smooth Muscle in Magnesium Deficiency and Vascular Remodeling: Possible Links to Atherogenesis, Hypertension and Cardiac Failure
}

\section{Editorial}

\author{
Altura $\mathrm{BM}^{1,2,3,4,5^{*}}$, Shah $\mathrm{NC}^{1,5}$, Gatha J. Shah ${ }^{1}$, Pérez-Abela JL ${ }^{6}$, Altura BT ${ }^{1,3,4,5}$
}

${ }^{1}$ Department of Physiology \& Pharmacology, SUNY Downstate Medical Center, Brooklyn, NY, USA.

${ }^{2}$ Department of Medicine, SUNY Downstate Medical Center, Brooklyn, NY, USA.

${ }^{3}$ Center for Cardiovascular and Muscle Research, SUNY Downstate Medical Center, Brooklyn, NY, USA.

${ }^{4}$ The School of Graduate Studies in Molecular and Cellular Science, State University of New York Downstate Medical Center, Brooklyn, NY, USA.

${ }^{5}$ Bio-Defense Systems, Inc, Rockville Centre, NY, USA.

${ }^{6}$ Instituto Bien de Salud, Lima, Peru.

Keywords: PAF; Sphingolipids; Atherosclerosis; Hypertension; Cardiac Failure; Ceramide.

\section{Introduction}

Platelet-activating factor (PAF) is a phospholipid mediator and cell signaling molecule which displays multiple biological and pathophysiological attributes, running the gamut from inflammation to cell differentiation and proliferation [1-4]. As is well-known, PAF interacts with specific membrane PAF-receptors (PAF-Rs) to initiate all cellular responses via specific G-proteincoupled receptors [1-4]. Although these initiated membrane receptor phenomena are mostly established for several tissuecell systems [1-8], exactly how PAF and PAF-Rs cause vascular remodeling in hypertension and atherosclerosis is not clear. A little more than 15 years ago, PAF was identified as a molecule that stimulated activation of nuclear factor-kappaB $(\mathrm{NF}-\mathrm{kB})[1$, $2,8]$.

\section{NF-kB, magnesium deficiency, PAF and sphingolipids}

$\mathrm{NF}-\mathrm{kB}$ is now known to be a prime regulator of growth processes, differentiation, cell migration, and cell death [for reviews, see [912], all factors required for vascular remodeling in hypertension and atherogenesis $[13,14]$. NF-kB is clearly a major transcription factor and a pleiotrophic regulator of numerous genes involved in inflammatory processes and epigenetic phenomena [9-12, 15]. $\mathrm{NF}-\mathrm{kB}$ is now thought to be a pivotal molecule in atherogenesis, hypertension, cardiac failure and stroke [14-19]. As of now, it is still not clear as to what factor(s) initiates expression of these molecular events. We were the first laboratory to suggest and provide evidence for a role for activation of $\mathrm{NF}-\mathrm{kB}$ in the cardiovascular manifestations, particularly atherogenesis, noted in magnesium deficiency (MgD) [20-22]. We demonstrated that when vascular smooth muscle (VSM) cells were exposed to low concentrations of extracellular, ionized $\mathrm{Mg}\left(\left[\mathrm{Mg}^{2+}\right]_{0}\right)$, a concentration-dependent upregulation of NF-kB took place; the lower the $\left[\mathrm{Mg}^{2+}\right]_{0}$, the faster and greater the upregulation of NF$\mathrm{kB}$ [20-22]. A similar situation appears to have been reported for endothelial cells [23]. Recently, we have reported that lowering $\left[\mathrm{Mg}^{2+}\right]_{0}$ also results in a synthesis and release of activated PAF [24] concomitant with an upregulation of five major sphingolipid enzymatic pathways responsible for formation of ceramide and sphingosine, prior to NF-kB upregulation [18, 20, 21, 24-31].

\section{Magnesium deficiency and activation of sphingolipid pathways in cardiovascular tissues and cells}

The de novo synthesis of sphingomyelin is brought about via the action of serine palmitoyl-CoA transferase (SPT), 3-ketosphinganine reductase, ceramide synthase (CS), dihydroceramide desaturase, and SM synthase (SMS; ref [32]). SMS requires phosphatidylcholine (PC) and ceramide as substrates to manufacture SM and diacylglycerol (DAG; see ref. [32]). This reaction directly affects SM, PC, and ceramide as well as DAG levels

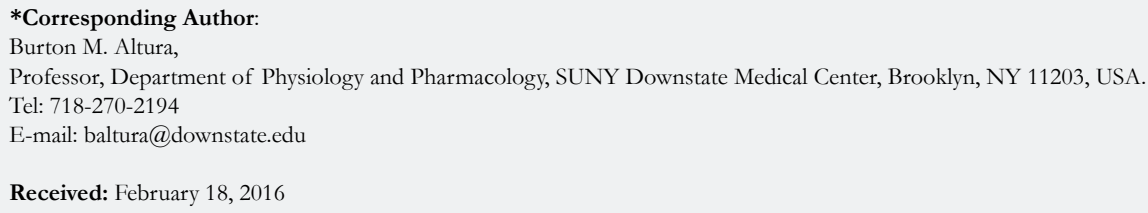

Citation: Altura BM et al., (2016) Insights into the Possible Mechanisms by Which Platelet-Activating Factor and PAF-receptors Function in Vascular Smooth Muscle in Magnesium Deficiency and Vascular Remodeling: Possible Links to Atherogenesis, Hypertension and Cardiac Failure. Int J Cardiol Res.. 3(1e), 1-3. doi: http://dx.doi.org/10.19070/2470-4563-160001e

Copyright: Altura $\mathbf{B M}^{\odot}$ 2016. This is an open-access article distributed under the terms of the Creative Commons Attribution License, which permits unrestricted use, distribution and reproduction in any medium, provided the original author and source are credited. 
in cells. Two of us $[21,33]$ have previously noted, using primary cerebral, coronary, and peripheral VSM cells in culture, as well as intact ventricular and atrial myocardial muscle obtained from rats after 21 days of short-term $\mathrm{MgD}$ [25-37], that variation of $\left[\mathrm{Mg}^{2+}\right]_{0}$ influences the cellular levels of SM, PC, DAG, sphingosine, and ceramide. Our in vitro and in vivo studies clearly demonstrated that low $\left[\mathrm{Mg}^{2+}\right]_{0}$ resulted in cellular synthesis and release of ceramide due to upregulation of SPT 1 and SPT 2, CS, SMS synthase, and a "salvage pathway" [25-31]. Ceramide is now thought to play important roles in fundamental pathophysiologic processes such as cell proliferation, membrane-receptor functions, angiogenesis, atherogenesis, immune inflammatory responses, cell adhesion, programmed cell death (i.e., apoptosis), and senescence among other functions [18, 25-31, 33-39]. It should be recalled, here, that $\mathrm{MgD}$ environments, both in vivo and in vitro, have repeatedly been shown to produce arterial and arteriolar contraction, vasospasm and vascular remodeling [18, 20, 22, 40-51], which we have demonstrated to involve ceramide (and other sphingolipids), PAF, cellular entry and intracellular release of free $\mathrm{Ca}^{2+}$, and activation of PKC isozymes, mitogen-activated protein kinases (MAPKs), MAPK kinases, tyrosine protein kinases, P-I-3 kinases, and PAF among other cellular signaling molecules [18, 24, 33, 40-51].

\section{PAF, magnesium deficiency, ceramide, and activation of proto-oncogenes}

The proto-oncogene families, particularly c-fos and c-jun, are two principal players in regulation of cell growth, differentiation, cell migration, and cell death; all important factors in vascular remodeling, as particularly observed in at herogenesis, hypertension, and cardiac failure $[11,13,14]$. It is, however, not clear how these proto-oncogenes are activated in vascular disease processes. Approximately 15 years ago, we discovered that low $\left[\mathrm{Mg}^{2+}\right]_{0}$ resulted in upregulation of both c-fos and c-jun in several types of VSM cells; the lower the $\left[\mathrm{Mg}^{2+}\right]_{0}$, the faster and the greater the magnitudes of the upregulation of these two proto-oncogenes [22]. In addition, we found that rats given diets reduced in $\mathrm{Mg}$ for 21 days resulted in upregulation of c-fos and c-jun in ventricular and atrial myocardial muscle cells [29]. Reduction in extracellular calcium levels resulted in inhibition of these events [22]. Very recently, we reported that exposure of several types of primary cultured VSM cells, from at least three different mammalian species, to low $\left[\mathrm{Mg}^{2+}\right]_{0}$ promoted synthesis and release of PAF and ceramide prior to upregulation of the proto-oncogenes [24]. In very recent experiments, we found that use of several different, specific antagonists of PAF-Rs attenuated, greatly, the PAFstimulated formation of the proto-oncogenes and ceramide in several types of primary cultured VSM cells, pointing to a novel, new pathway in $\mathrm{MgD}$ [[24]; unpublished findings ].

\section{Conclusions}

We believe our new findings on PAF, proto-oncogenes, and sphingolipids, e.g, ceramide and sphingosine, probably point to fundamental roles for the upstream regulation of both protooncogenes and sphingolipids in both VSM and cardiac muscle cells. These new, exciting findings probably will also be helpful in explaining many of the known cardiovascular manifestations of $\mathrm{MgD}$, particularly vascular remodeling seen in atherosclerosis and hypertension. Last, but not least, our new studies should be useful in future studies designed to counteract many of the cardiovascular manifestations of $\mathrm{MgD}$.

\section{Acknowledgments}

Some of the original studies mentioned in this report were supported, in part, by Research Grants from The National Heart, Lung and Blood Institute, The National Institute on Drug Abuse, The National Institute on Mental Health and The National Institute on Alcoholism and Alcohol Abuse awarded to B.M.A. and B.T. A.

\section{References}

[1]. Chao W, Olson MS (1993) Platelet-activating factor: receptors and signal transduction. Biochem J 292(Pt 3): 617-629.

[2]. Prescott SM, Zimmerman GA, Stafforini DM, McIntyre TM (2000) Platelet-activating factor and related lipid mediators. Annu Rev Biochem 69: 419-450.

[3]. Zimmerman GA, McIntyre TM, Prescott SM, Stafforini DM (2002) The platelet-activating factor signaling system and its regulators in syndromes of inflammation and thrombosis. Crit Care Med 30(5 Suppl): S294-S301.

[4]. Montrucchio G, Alloatti G, Camussi G (2000) Role of platelet-activating factor in cardiovascular pathophysiology. Physiol Rev 80(4): 1669-1699.

[5]. Claing A, Shbaklo H, Plante M, Bkaily G, D'Orleans-Juste P (2002) Comparison of the contractile and calcium-increasing properties of platelet-activating factor and endothelin in the rat mesenteric artery and vein. $\mathrm{Br} \mathrm{J}$ Pharmacol 135(2): 433-443.

[6]. Lang PA, Kempe DS, Tanneur V, Eisle K, Klarl BA, et al. (2005) Stimulation of erythrocyte ceramide formation by platelet-activating factor. J Cell Sci 118 (Pt 6): 1233-1243.

[7]. Ying-fang S, Jing-fang H, Huan-zhang L, Hao-wen Q (2007) Effect of platelet-activating factor on cell proliferation \& NF-kappaB activation in airway smooth muscle cells in rats. Indian J Med Res 126(2): 139-145.

[8]. Predescu S, Knezevic I, Bardita C, Neamu RF, Brovcovych V, et al. (2013) Platelet-activating factor -induced ceramide micro-domains drive endothelial NOS activation and contribute to barrier dysfunction. PLOS One 8(9): e75846.

[9]. Barnes PJ, Karin M (1997) Nuclear factor-kappaB--A pivotal transcription factor in chronic inflammatory disease. N Engl J Med 336(15): 1066-1071.

[10]. Baeuerle PA, Baltimore D (1996) NF-kappaB: ten years after. Cell 87(1): 13-20.

[11]. Ransone LJ, Verma IM (1990) Nuclear proto-oncogenes fos and jun. Annu Rev Cell Biol 6: 539-557.

[12]. Hayden MS, Ghosh S (2011) NF-kB in immunology. Cell Res 21(2): 223 244.

[13]. Intengan HD, Schiffrin EL (2001) Vascular remodeling in hypertension: roles of apoptosis, inflammation, and fibrosis. Hypertension 38(3 Pt 2): 581-587.

[14]. Kumar V, Abbas AK, Fasuto N, Aster JC (2010) Robbins and Cotran Pathologic Basis of Disease. ( $8^{\text {th }}$ edtn), Saunders, Philadelphia.

[15]. Bourcier T, Sukhova G, Libby P (1997) The nuclear factor kappa-B signaling pathway participates in dysregulation of vascular smooth muscle in vitro and in human atherosclerosis. J Biol Chem 272(25): 15817-15824.

[16]. Momaco C, Andreakos E, Kirkadidis S, Mauri C, Bicknell C, et al. (2004) Canonical pathway of nuclear factor kappa $\mathrm{B}$ activation selectively regulates proinflammatory and prothrombotic responses in human atherosclerosis. Proc Nat Acd Sci USA 101(15): 5634-5639.

[17]. Altura BM, Altura BT (2007) Magnesium: forgotten mineral in cardiovascular biology and angiogenesis. In New Perspectives in Magnesium Research. Springer, London. 239-260.

[18]. Hansson GK, Hermansson A (2011) The immune system in atherosclerosis. Nat Immunol 12(3): 204-212.

[19]. Altura BM, Altura BT (1995) Magnesium and cardiovascular biology: an important link between cardiovascular risk factors and atherogenesis. Cell Mol Biol Res 41(5): 347-359.

[20]. Morrill GA, Gupta RK, Kostellow AB, Ma GY, Zhang A, et al. (1998) $\mathrm{Mg}^{2+}$ modulates membrane sphingolipids and lipid second messenger levels in vascular smooth muscle cells. FEBS Lett 440(1-2): 167-171.

[21]. Altura BM, Kostellow AB, Zhang A, Li W, Morrill GA, et al. (2003) Expression of the nuclear factor-kappaB and proto-oncogenes c-fos and c-jun are induced by low extracellular $\mathrm{Mg}^{2+}$ in aortic and cerebral vascular smooth muscle cells: possible links to hypertension, atherogenesis, and stroke. Am J Hypertens 16(9 Pt 1): 701-707. 
[22]. Maier JA (2012) Endothelial cells and magnesium: implications in atherosclerosis. Clin Sci 122(9): 397-407.

[23]. Altura BM, Li W, Zhang A, Zheng T, Shah NC, et al. (2016) Expression of PAF is induced by low extracellular $\mathrm{Mg}^{2+}$ in aortic, cerebral and piglet coronary arterial vascular smooth muscle cells: cross-talk with ceramide production, DNA, nuclear factor-kB and proto-oncogenes: possible links to inflammation, atherogenesis, hypertension, sudden cardiac death in children and infants, stroke, and aging; hypothesis and review. Int J Clin Exp Med, in press.

[24]. Altura BM, Shah NC, Li Z, Jiang XC, Perez-Albela JL, et al. (2010) Magnesium deficiency upregulates serine palmitoyl transferase (SPT 1 and SPT 2) in cardiovascular tissues: relationship to serum ionized $\mathrm{Mg}$ and cytochrome C. Am J Physiol Heart Circ Physiol 299(3): H932-H938.

[25]. Altura BM, Shah NC, Li Z, Jiang XC, Zhang A, et al. (2010) Short-term magnesium deficiency upregulates sphingomyelin synthase and $\mathrm{p} 53$ in cardiovascular tissues and cells: relevance to the de novo synthesis of ceramide. Am J Physiol Heart Circ Physiol 299(6): H2046-H2055.

[26]. Altura BM, Shah NC, Shah G, Zhang A, Li W, et al. (2012) Short-term magnesium deficiency upregulates ceramide synthase in cardiovascular tissues and cells: cross-talk among cytokines, $\mathrm{Mg}^{2+}, \mathrm{NF}-\mathrm{kB}$, and de novo ceramide. Am J Physiol Heart Circ Physiol 302(1): H319-H332.

[27]. Shah NC, Liu JP, Iqbal J, Hussain M, Jiang XC, et al. (2011) Mg deficiency results in modulation of serum lipids, glutathione, and NO synthase isozyme activation in cardiovascular tissues: relevance to de novo synthesis of ceramide, serum $\mathrm{Mg}^{2+}$ and atherogenesis. Int J Clin Exp Med 4(2): 103-118.

[28]. Altura BM, Shah NC, Shah GJ, Li W, Zhang A, et al. (2013) Magnesium deficiency upregulates sphingomyelinases in cardiovascular tissues and cells: cross-talk among proto-oncogenes, $\mathrm{Mg}^{2+}, \mathrm{NF}-\mathrm{kB}$ and ceramide and their potential relationships to resistant hypertension, atherogenesis and cardiac failure. Int J Clin Exp Med 6(10): 861-879.

[29]. Altura BM, Shah NC, Shah GJ, Zhang A, Li W, et al. (2014) Short-term magnesium deficiency upregulates protein kinase $\mathrm{C}$ isoforms in cardiovascular tissues and cells; relation to NF-kB, cytokines, ceramide salvage sphingolipid pathway and PKC-zeta: hypothesis and review. Int J Clin Exp Med 7(1): $1-21$.

[30]. Shah NC, Shah GJ, Li Z, Jiang XC, Altura BT, et al. (2014) Short-term magnesium deficiency downregulates telomerase, upregulates neutral sphingomyelinase and induces oxidative DNA damage in cardiovascular tissues: relevance to atherogenesis, cardiovascular diseases and aging. Int J Clin Exp Med 7(3): 497-514.

[31]. Merrill AH Jr, Jones DD (1990) An update of the enzymology and regulation of sphingomyelin metabolism. Biochim Biophys Acta 1044(1): 1-12.

[32]. Morrill GA, Gupta RK, Kostellow AB, Ma GY, Zhang A, et al. (1997) $\mathrm{Mg}^{2+}$ modulates membrane lipids in vascular smooth muscle: a link to atherogenesis. FEBS Lett 408(2): 191-194.

[33]. Haimovitz-Friedman A, Kolesnick RN, Fuks Z (1997) Ceramide signaling in aoptosis. Br Med Bull 53(3): 539-553.

[34]. Hannun YA, Obeid LM (2002) The ceramide-centric universe of lipidmediated cell regulation: stress encounters of the lipid kind. J Biol Chem 277(29): 25847-25850.

[35]. Andrieu-Abadie N, Gouaze V, Salvayre R, Levade T (2001) Ceramide in apoptosis signaling: relationship with oxidative stress. Free Radic Biol Med 31(6): 717-728

[36]. Augé N, Nègre-Salvayre A, Salvayre R, Levade T (2000) Sphingomyelin metabolites in vascular signaling and atherosclerosis. Prog Lipid Res 39(3): 207-239.

[37]. Pandey S, Murphy RF, Agrawal DK (2007) Recent advances in the immunobiology of ceramide. Exp Mol Pathol 82(3): 298-309.

[38]. Villani M, Subathra M, Im YR, Choi Y, Signorelli P, et al. (2008) Sphingomyelin synthases regulate production of diacylglycerol at the Golgi. Biochem J 414(1): 31-41.

[39]. Altura BM, Altura BT (1974) Magnesium and contraction of arterial smooth muscle. Microvasc Res 7(2): 145-155.

[40]. Altura BM, Altura BT (1978) Magnesium and vascular tone and reactivity. Blood Vessels 15: 5-16.

[41]. Altura BT, Altura BM (1980) Withdrawal of magnesium causes vasospasm while elevated magnesium produces relaxation of tone in cerebral arteries. Neurosci Lett 20(3): 323-327.

[42]. Turlapaty PD, Altura BM (1980) Magnesium deficiency produces spasms of coronary arteries: relationship to etiology of sudden death ischemic heart disease. Science 208(4440): 198-200.

[43]. Altura BM, Altura BT (1981) Magnesium and contraction of vascular smooth muscles: relationship to some vascular diseases. Fed Proc 40(12): 2672-2679.

[44]. Altura BM, Altura BT, Carella A, Turlapaty PD (1981) Hypomagnesemia and vasoconstriction: Possible relationship to etiology of sudden death ischemic heart disease and hypertensive vascular diseases. Artery 9(3): 212 231.

[45]. Altura BM, Turlapaty PD (1982) Withdrawal of magnesium enhances coronary arterial spasms produced by vasoactive agents. Br J Pharmacol 77(4): 649-659.

[46]. Altura BM, Altura BT, Carella A (1983) Magnesium deficiency-induced spasms of umbilical vessels: relation to preeclampsia, hypertension, growth retardation. Science 221(4608): 376-378.

[47]. Altura BM, Altura BT, Gebrewold A, Ising H, Gunther T (1984) Magnesium deficiency and hypertension: correlation between magnesium-deficient diets and microcirculatory changes in situ. Science 223(4642): 1315-1317.

[48]. Yang ZW, Wang J, Altura BT, Altura BM (2000) Extracellular Magnesium deficiency induces contraction of arterial muscle: role of PI3 kinases and MAPK signaling pathways. Pflug Arch 439(3): 240-247.

[49]. Yang ZW, Wang J, Zheng T, Altura BT, Altura BM (2000) Low extracellular $\mathrm{Mg}^{2+}$ induces contraction and $\left[\mathrm{Ca}^{2+}\right]$ i rises in cerebral arteries: roles of $\mathrm{Ca}^{2+}$, PKC and PI-3 kinases. Am J Physiol Heart Circ Physiol 279: H2898$\mathrm{H} 2907$.

[50]. Yang ZW, Wang J, Zheng T, Altura BT, Altura BM (2000) Low extracellular $\mathrm{Mg}$ induces contraction of cerebral arteries: roles of tyrosine and mitogen-activated protein kinases. Am J Physiol Heart Circ Physiol 279(1): H185-H194. 